\section{Cultivar Evaluation}

\section{Variation in the Cooked and Chipping Quality of Taro}

\author{
Robert E. Paull, ${ }^{1}$ Gail U ruu, ${ }^{1}$ \\ and Alton Arakaki²
}

Additional indeX words. taste, poi, boiled taro, acridity

Summary. Taro [C docasia esculenta (L.) Schott] corms from 57 vegetatively propagated cultivars were evaluated for yield, physical and chemical characteristics, and either microwaved, microwaved and ground into poi, or fried. Poi color ranged from purple to orange or yellow and the dry matter content from 18.3 to $48 \%$ T he taste panel preferred poi made from a number of other cultivars than that made from the most common cultivar 'L ehua M aoli' used in $\mathrm{H}$ awaii, and a darker bluishred poi was preferred. Corm total

Thisisthe College of Tropical Agriculture and $\mathrm{H}$ uman Resources journal series number 4503. The research was supported in part by grants from the $\mathrm{H}$ awaii Governor'sAgricultural C oordinating Committee(91/

$15)$ and the U.S. D epartment of Agriculture Special Diversification G rant (U SD A-C SR S88-34172-3310). We thank $\mathrm{N}$ ancy $\mathrm{C}$ hen, $\mathrm{M}$ aria Eloisa $\mathrm{Q}$. Reyes, Achie Reyes, and Wendy Kimura for technical help. The cost of publishing this paper was defrayed in part by the payment of page charges. Under postal regulations, this paper therefore must be hereby marked advertise ment solely to indicate this fact.

${ }^{1}$ D epartment of Tropical Plant and Soil Sciences and Cooperative Extension Service, U niversity of $\mathrm{H}$ awaii M anoa, $3190 \mathrm{M}$ aileWay, $\mathrm{H}$ onolulu, H I 96822-2279.

${ }^{2} \mathrm{C}$ ollegeof T ropical Agricultureand $\mathrm{H}$ uman Resources, U niversity of $\mathrm{H}$ awaii $\mathrm{M}$ anoa, $3190 \mathrm{M}$ aile Way, $\mathrm{H}$ onolulu, H I 96822-2279. soluble solids were positively correlated to corm specific gravity and dry matter, and to the taste preference of microwaved corm and poi. The fried cultivars varied widely in yield and corm color varied from cream to white. Additionally, some cultivars did not have purple vascular bundles, and others were acrid after frying. Chip oil content was negatively correlated to corm weight, dry weight, and chip yield. The 'B in Liang' cultivar was judged the best overall in fried chip taste. Considerable variation in corm yield and quality characteristics existed in this widely cultivated vegetatively propagated tropical crop.

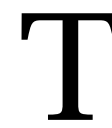
aro is cultivated throughout the tropics and subtropicsof theworld (Plucknett et al., 1970). All parts of the plant can be eaten, although cooking is required before eating (Plucknett, 1970) due to the presence of an unknown acrid principle (Paull et al., 1999). The corm is dried for flour, baked, boiled or fried prior to eating. In $\mathrm{H}$ awaii, the bulk of the cormsareboiled or steamed, peeled and ground to poi, a paste-like food. A different cultivar 'Bin Liang' is fried to make chips and steamed or boiled as a starch staple.

M ost cultivars are vegetatively propagated selections, and considerable variation exists in plant size, type, color and corm characteristics. $M$ any cultivars and wild forms $(1,417)$ have been collected (Lebot and Aradhya, 1991). Whitney et al. (1939) described 84 poi typesin $\mathrm{H}$ awaii, based on leaf shape, leaf color, leaf venation, petiole size, and color, corm flesh color, corm fibers color and skin color. O ccasionally, starch properties, acridity, color of poi, and culinary uses are used for classification. $M$ any proximate analyses of taro flour and poi are reported (Bradbury, 1988). Payne et al. (1941) reported that dryland taro contains less starch but more complex sugars and ash than wetland cultivars. Taro starch is mainly amylose with smaller amounts of amylopectin (Amin, 1955) and is readily digested after preparation aspoi (Standal, 1970). This study objective was to determine the variation between taro cultivars in the quality of corms used to make a boiled or microwaved food, or made into poi and fried as chips.

\section{Materials and methods}

Plant material. Thecultivarsfrom Fujian Agricultural College, Fuzhou, China(FAC) (Zhang and Zhang, 1990) and Gaoxiong Agricultural Improvement Station, Taiwan, were compared with the local cultivars (Table 1 ). The $\mathrm{H}$ awaiian taro cultivars used to make poi were from the U niversity of $\mathrm{H}$ awai' $\mathrm{i}$ at $M$ anoa, and all were grown on the M oloka'i R esearch and D emonstration Farm located at $\mathrm{H}$ o'olehua, M oloka'i, H awai'i (157 4' 12"W, $21^{\circ} 8^{\prime} 15^{\prime \prime} \mathrm{N}$ ). Theelevation was $40 \mathrm{~m}$ (131 ft), with an average annual rainfall of $48 \mathrm{~cm}$ (18.9 inches) per year and a daily mean temperature of $22.5^{\circ} \mathrm{C}\left(72.5^{\circ} \mathrm{F}\right)$. T he soil wasan oxisol, low-humic latosols of the H olomua soil series.

Field PREPARATION, PLANTING, AND MANAGEMENT. The field was plowed, tilled and dolomite was broadcast and tilled into the field at the rate of 2242 $\mathrm{kg} \cdot \mathrm{ha}^{-1}$ ( 1.23 tons/ acre) to adjust $\mathrm{pH}$ to 6.5 , and to provide calcium and magnesium. Planting furrows, $20 \mathrm{~cm}$ (8 inch) deep were cut $144 \mathrm{~cm} \mathrm{(56}$ inch) apart. Fertilizer (10N-8.7P16.6K) was incorporated into the furrow at a rate of $560 \mathrm{~kg} \cdot \mathrm{ha}^{-1}(0.3$ tons/ acre). D rip irrigation lines were laid into the furrowed planting rows and emitters were spaced $30 \mathrm{~cm}$ (12 inches) apart. I rrigation was applied at a rate of 188.3 $\mathrm{mm} \cdot \mathrm{ha}^{-1} \cdot$ week $^{-1}$ ( 3 inches/ acre/ week).

The top of the corm and $20 \mathrm{~cm}$ ( 8 inch) of the petiole were cut and dipped in sodium hypochlorite $(2 \% \mathrm{v} / \mathrm{v})$ to disinfect the material, dried for a day at ambient temperature, and planted at oneplant per meter (1 plant/ 39 inches) in the furrow rows along the drip line. Plants were hilled 6 weeks after planting to cover 10 to $15 \mathrm{~cm}$ (4 to 6 inches) of the petiole and to bury the drip irrigation lines 30 to $35 \mathrm{~cm}$ (12 to 14 inches).

A combination of pre- and 
T able 1. Physical characteristics of taro cultivars used for boiled products and fried as chips.

\begin{tabular}{ll}
\hline Cultivar (local name) & Petiole color (top/middle/base) \\
\hline Bin Liang (H awaii) & Purple/ light green/ white, pinkish ring \\
Bin Liang Xin & Light purple/ light green/ white \\
FAC Specialy & Purple hue/ light green/ white, purple ring \\
Feng H uang (Phoenix) & Red hue/ light green/ white with pink ring \\
Gaoxiong \#1 & Dark purple/ light green/ white \\
Guang Zhou Shang Yue (fragrant taro) & Purple hue/ light green/ white, pinkish ring \\
Guo Ti Yu (dog log taro) & Purple/ light green/ white \\
$\mathrm{H}$ ai N an N an Da & Purple/ light green/ white, pinkish ring \\
$\mathrm{H}$ ong Geng Yu (red stem taro) & Black/ black/ white, light green \\
Long Bin Liang Shan & Purple hue/ light green/ white, light pink ring \\
$\mathrm{M}$ ian Yu (noodle taro) & Light pink/ light green/ white with light green hue \\
$\mathrm{N}$ an An (Southern Peace) & Purple hue/ light green/ white with red hue ring \\
Si M ao Yu (brown tip taro) & Dark purple/ green with black hue, white edge/ light green tinted black hue
\end{tabular}

zThe piko is the spot on the upper surface of the leaf at the junction point of the petiole and leaf. The sinus depth refers to the petiole.

yFAC Fujian Agricultural College, Fuzhou, China.

postemergenceherbicides and field cultivation were used to manage weeds. Potassium chloridewassidedressed during the hilling operation at the rate of $224 \mathrm{~kg} \cdot \mathrm{ha}^{-1}$ (0.12 tons/ acre). N itrogen, at the rate of $280 \mathrm{~kg} \cdot \mathrm{ha}^{-1}(0.15$ tons/ acre), divided equally at 3 and 6 months after planting, was applied via fertigation.

The green peach aphid (Myzus persicae Sulzer) and the Chinese rose beetle (A dor etus sinicus Burmeister) were the primary insect pests. Corm rot wasgenerally caused by Pythium sp. and associated with root knot nematodes $M$ eloi dogyne sp. No insecticides or fungicides were applied as the overall damage was minimal.

Plant maturity and data collecTION. The corm was regarded as mature when the mother plant leaves senesced and occurred by 12 months after planting, when all corms were harvested. Plants were pulled from the ground and cormels separated from the main corm. The individual main corms were weighed, and the volume determined by water displacement to determine specific gravity. The yield data does not include the weight of the cormels.

A colorimeter (Chromameter model CR-100; M inolta, Ramsey, N .J.) was used to determine corm flesh color on a freshly cut corm surface with " $L$ " lightness, "a" red to green and " $b$ " blue to yellow. The " $a$ " and " $b$ " were converted to chroma and hue (M cGuire, 1992), chroma being the saturation (e.g., lightness, vividness, dullness) of a color whilehueisthe color. Cormswere peeled, grated, and piecesweresqueezed using a hand garlic press to express liquid, and the liquid centrifuged. A refractometer was used to determine total soluble solids on the supernatant. Grated corm [ $10 \mathrm{~g}(0.35 \mathrm{oz})]$ was dried at $90{ }^{\circ} \mathrm{C}$ (194 $\left.{ }^{\circ} \mathrm{F}\right)$ for 48 hours, reweighed and the percent dry weight calculated. G rated corm [ $2 \mathrm{~g}(0.07 \mathrm{oz})$ ] washomogenized in $18 \mathrm{~mL}(0.61 \mathrm{fl} \mathrm{oz})$ $95 \%$ ethanol and the extract used to determine phenols and total sugars. Phenol was assayed by the procedure of Singleton and Rossi (1965) with catechol as standard. Total sugars were determined by the phenol-sulfuric acid procedure of D uboiset al. (1956), with glucose as standard.

Chip preparation and evaluation. The corms were weighed, peeled and sliced [ $1.2 \mathrm{~mm}$ (0.05 inches)]. The slices $(250 \mathrm{~g}, 82 \mathrm{oz})$ were placed into vegetableoil at $160^{\circ} \mathrm{C}\left(320^{\circ} \mathrm{F}\right)$ and the oil temperature dropped to ca. $140{ }^{\circ} \mathrm{C}$ $\left(284^{\circ} \mathrm{F}\right)$, before the bath began to automatically reheat. Chips were removed when most of the boiling had subsided $\left[150^{\circ} \mathrm{C}\left(302^{\circ} \mathrm{F}\right)\right]$, the time used varied with cultivar dry matter content and the reduction in boiling is used as a commercial indicator of frying end point. The fried chips were spun in a salad spinner to remove excess oil and reweighed to determine percent chip yield. Fried chips [ $30 \mathrm{~g}(1.06 \mathrm{oz})]$ were ground for 10 sin a small kitchen coffee mill and the color determined using the Colorimeter. The ground chips [2 $\mathrm{g}$ $(0.07 \mathrm{oz})]$ were washed three times with $20 \mathrm{~mL}(0.68 \mathrm{fl} \mathrm{oz})$ of acetone to extract oil, dried in air $\left(22.5^{\circ} \mathrm{C}, 72.5\right.$ $\left.{ }^{\circ} \mathrm{F}\right)$, reweighed and the percentage of oil in the chips calculated.

Ten sensory panelists of various ethnic groups were first trained and then ranked every batch of chips for appearance, crispness and taste on a scale of 0 to 5 , with 5 being the best score. Chip appearance was intended to measure overall color, chip oil soaking as translucency, and the degree of chip folding that occurred during frying.

POI AND BOILED CORM PREPARATION. Corms were peeled, cut into chunks, placed in abowl with $10 \mathrm{~mL}(0.34 \mathrm{fl} \mathrm{oz})$ of water, covered with plastic wrap and microwaved on high power (1100 W) for $8 \mathrm{~min}$. The cooked taro was presented to taste panel members directly asamicrowaved product or run through a meat grinder that had $3 \mathrm{~mm}(0.12$ inch) holes in the extrusion plate and presented to the panel members as poi.

TASTE PANEL COMPOSITION. T wentyone M oloka'i members of the Alu Like, Ke O la Pono N o N a Kupuna Program, a nutritional program for $\mathrm{N}$ ative $\mathrm{Ha}$ waiian elderly, participated on the taste panel. All of the participants were over 60 years of age and consumed taro as a regular part of their diet. M embers of the panel were asked to evaluate overall tasteand preference, and mark the sheet on a 0 to 5 scale, with 5 being the best score.

Statistical analysis. Data were analyzed by GLM and correlation and regression procedure (SAS Institute, $C$ ary, N .C.). M eans were compared ( $P$ $=0.05$ ) by the $D$ uncan-Waller $k$ ratio $t$ test and standard deviation.

\section{Results and discussion}

Fried AND boiled CULTIVARS. The cultivars are identified by petiole color (Zhang and Zhang, 1990), that varies from red to a purpleand black hueat the top to white with a pinkish ring to light green (Table 1). Corm color varied 


\section{Corm color (flesh/fibers)}

Chalky white/ purple

White/ purple

Cream/ purple

Creamy yellow/ purple

Cream/ purple

Chalky white/ purple

White/ purple

Chalky white/ purple

Chalky white/ yellow, cormels on long slender rhizomes

Cream/ purple

Chalky white/ yellow

Creamy white/ purple

Chalky white/ yellow
Leaf (shape/ color/ pikoz color/ sinus depth)

O vate/ green/ purple/ shallow

Sagittate/ light green/ dark purple/ shallow

O vate/ green/ purple/ shallow

Broadly O vate/ green/ purple/ shallow

O vate/ light green/ purple/ shallow

O vate/ green/ purple/ shallow, wide

O vate/ light green/ purple/ shallow

O vate/ green/ purple/ shallow

Sagittate/ dark green/ purple/ shallow

Sagittated/ green/ purple/ shallow

O vate/ dark green/ white/ shallow

O vate/ green/ purple/ shallow

O vate/ dark green/ lavender/ shallow leaves are upright, almost perpendicular to ground from cream to chalky white. Purple vascular fibers in the corm, a marked feature of the local 'Bin Liang' cultivar, were not present in all cultivars. Leaf shape can also be used as an aid in identification, with marked differences in shape, piko color (the spot on the upper leaf surface at the point of juncture to the petiole), and petiole sinus depth. ' $\mathrm{H}$ ong $\mathrm{G}$ eng $\mathrm{Yu}^{\mathrm{\prime}}$ ', atriploid from eastern China (Zhang and Zhang, 1990), was unique in having long slender rhizomes connecting the cormels.

The local $H$ awaii 'B in Liang' gave thehighestyield at 7 monthsof age. The non- $\mathrm{H}$ awaii cultivarsyieldsvaried widely; theF ujian cultivarshad thehighest yield, followed by 'Gaoxiong \#1' (Table 2). The corm weight of individual cultivar varied 2.7 fold, while the specific gravity was similar for all cultivars. D ry matter

Table 2. Corm characteristics of taro cultivars used for microwaved corm and fried chips.

\begin{tabular}{|c|c|c|c|c|c|c|c|}
\hline Cultivar/notes ${ }^{2} /$ source & $\begin{array}{c}\text { Yieldy }^{y} \\
\left(\text { kg:ha' }^{-1}\right)\end{array}$ & $\begin{array}{l}\text { Wt } \\
(g)\end{array}$ & $\begin{array}{l}\text { Specific } \\
\text { gravity }\end{array}$ & $\begin{array}{c}\text { Dry matter } \\
(\%)\end{array}$ & $\begin{array}{l}\text { TSS }^{\mathrm{x}} \\
(\%)\end{array}$ & $\begin{array}{l}\text { Phenol } \\
\text { (mg. } \mathrm{g}^{-1} \\
\text { fresh wt) }\end{array}$ & $\begin{array}{c}\text { Sugar } \\
\left(\mathrm{mg} \cdot \mathrm{g}^{-1}\right. \\
\text { fresh wt) }\end{array}$ \\
\hline Bin Liangw & & & & & & & \\
\hline $\begin{array}{l}\text { Local cultivar, } \mathrm{H} \text { awaii } \\
\text { Bin Liang Xin }\end{array}$ & 14,157 & $683 b^{v}$ & $0.99 \mathrm{bcd}$ & $65.5 f$ & $10.2 \mathrm{a}$ & 329.9 de & $8.52 \mathrm{~cd}$ \\
\hline $\begin{array}{l}\text { KCC-038, G aoxiong, T aiwan } \\
\text { FAC Special }\end{array}$ & 7,492 & $385 \mathrm{C}$ & $0.98 \mathrm{bcd}$ & $78.8 \mathrm{a}$ & $7.7 \mathrm{c}$ & 381.8 bc & $10.99 \mathrm{~b}$ \\
\hline $\begin{array}{l}\mathrm{H} \text { igh Starch C hinese Poi, Fuzhou, PRC } \\
\text { Feng } \mathrm{H} \text { uang } \\
\text { Eastern Guangdong }\end{array}$ & 15,464 & $684 \mathrm{~b}$ & $0.98 \mathrm{~cd}$ & $68.5 \mathrm{de}$ & $6.8 \mathrm{~d}$ & $343.7 \mathrm{~cd}$ & $8.96 \mathrm{bcd}$ \\
\hline $\begin{array}{l}\text { Province, China, Fuzhou, PRC } \\
\text { Gaoxiong \#1 }\end{array}$ & 12,415 & $626 \mathrm{~b}$ & $0.98 \mathrm{bcd}$ & $65.0 \mathrm{f}$ & $6.8 d$ & $144.6 \mathrm{~g}$ & $5.22 \mathrm{f}$ \\
\hline $\begin{array}{l}\text { KCC-033, Gaoxiong, Taiwan } \\
\text { Guang Zhou Shang Yue }\end{array}$ & 14,157 & $713 a b$ & $1.00 \mathrm{bc}$ & 66.9 ef & $8.6 \mathrm{~b}$ & $292.8 \mathrm{e}$ & $7.77 \mathrm{de}$ \\
\hline $\begin{array}{l}\text { Fuzhou, PRC } \\
\text { Guo TiYu }\end{array}$ & 12,197 & $612 b$ & $0.97 \mathrm{~cd}$ & 67.2 ef & $6.4 \mathrm{~d}$ & $212.2 \mathrm{f}$ & 5.77 ef \\
\hline $\begin{array}{l}\text { KCC }-029, \mathrm{G} \text { aoxiong, Taiwan } \\
\mathrm{H} \text { ai } \mathrm{Nan} \mathrm{N} \text { an Da }\end{array}$ & 6,795 & $315 \mathrm{~cd}$ & $1.01 \mathrm{ab}$ & $73.7 b c$ & $6.8 \mathrm{~d}$ & $368.0 \mathrm{bcd}$ & $1.01 \mathrm{bc}$ \\
\hline $\begin{array}{l}\text { Name of city-West } \mathrm{H} \text { ainan, Fuzhou, PRC } \\
\mathrm{H} \text { ong Geng Yu }\end{array}$ & 11,761 & $599 \mathrm{~b}$ & $0.91 \mathrm{e}$ & $71.0 \mathrm{~cd}$ & 6.0 ef & 331.1 cde & $10.66 \mathrm{~b}$ \\
\hline $\begin{array}{l}\text { KCC-002, G aoxiong, Taiwan } \\
\text { Long Bin Liang Shan Chuan }\end{array}$ & 6,316 & $315 \mathrm{~cd}$ & $0.97 \mathrm{~cd}$ & $75.5 \mathrm{~b}$ & $\cdots$ & $451.0 \mathrm{a}$ & $8.08 \mathrm{~cd}$ \\
\hline $\begin{array}{l}\text { Name of village, Fuzhou, PRC } \\
\text { M ian Yu }\end{array}$ & 5,227 & $260 d$ & $0.97 \mathrm{~d}$ & $71.7 \mathrm{c}$ & 6.4 de & $414.6 \mathrm{ab}$ & $10.12 \mathrm{bcd}$ \\
\hline $\begin{array}{l}\text { KCC-055, Gaoxiong, Taiwan } \\
\text { Nan An }\end{array}$ & 7,841 & $412 \mathrm{c}$ & $1.03 \mathrm{a}$ & $75.3 \mathrm{~b}$ & $\cdots$ & $362.6 \mathrm{~cd}$ & $8.38 \mathrm{~cd}$ \\
\hline $\begin{array}{l}\text { Protein OK, Fuzhou, PRC } \\
\text { Si M ao Yu }\end{array}$ & 16,771 & $808 a$ & $1.00 \mathrm{bcd}$ & 66.0 ef & $6.8 \mathrm{~d}$ & $180.0 \mathrm{fg}$ & $5.18 \mathrm{f}$ \\
\hline KCC-023, G aoxiong, T aiwan & 7,405 & $297 \mathrm{~cd}$ & $0.99 \mathrm{bcd}$ & $81.0 \mathrm{a}$ & $5.7 \mathrm{f}$ & $370.2 \mathrm{bcd}$ & $14.87 \mathrm{a}$ \\
\hline
\end{tabular}

$\overline{\mathrm{z} F \mathrm{AC}}=$ Fujian Agricultural College, Fuzhou, China; $\mathrm{KCC}=\mathrm{G}$ aoxiong Cultivar Improvement Farm, Gaoxiong, Taiwan.

${ }^{1} 1 \mathrm{~kg} \cdot \mathrm{ha}^{-1}=0.892 \mathrm{lbs} / \mathrm{acre} ; 1 \mathrm{~g}=0.035 \mathrm{oz} ; 1 \mu \mathrm{g} \cdot \mathrm{g}^{-1}=1 \mathrm{ppm} ; 1 \mathrm{mg} \cdot \mathrm{g}^{-1}=1000 \mathrm{ppm}$.

xTSS $=$ total soluble solids.

wBin liang $\mathrm{H}$ awaii cultivar was 7 months old, while all others were harvested when 12 months old. $\mathrm{N}$ o cormel weights were included.

${ }^{V} M$ eans followed by the same letter were not significantly different $(P<0.05)$ by Waller-D uncan $k$ ratio $t$ test. 
T able 3. Q uality characteristics of chips made from taro cultivars grown for microwaved corms and chips.

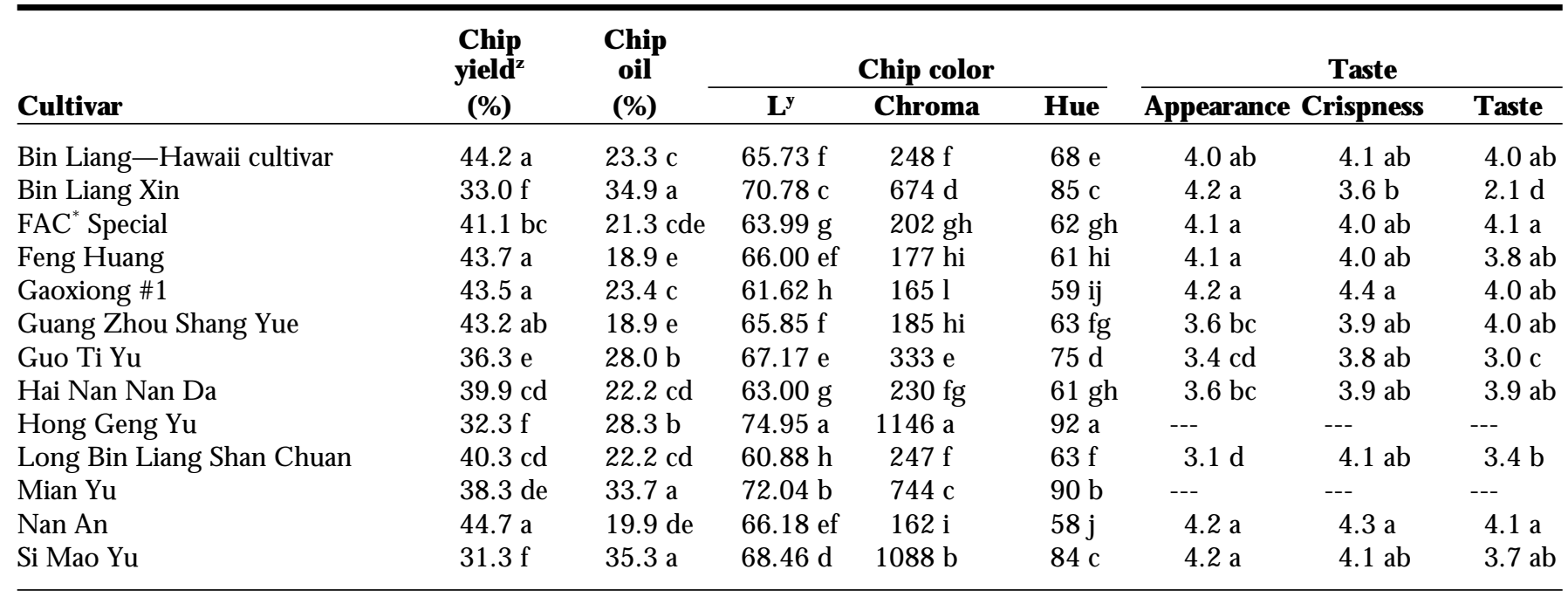

${ }_{\mathrm{z} M}$ eans followed by the same letter were not significantly different $(\mathrm{P} \leq 0.05)$ by $\mathrm{D}$ uncan Waller $\mathrm{k}$ ratio $\mathrm{t}$ test.

$\mathrm{y}^{\prime} \mathrm{L}$ ' Commission Internationale de I'E clairage (CIE), lightness value, dark to light.

percentage varied from $65 \%$ to $81 \%$ and total soluble solids from $5.7 \%$ to $8.6 \%$ The sugar content was not significantly related to total soluble solids. Phenols content that could impart astingency to a boiled or fried product varied over a3fold range. The total sugar and phenol content of boiled and fried chips from 'Bin Liang' was in the middle of the range.

Chips from ' $\mathrm{H}$ ong Geng $\mathrm{Yu}$ ', the only cultivar with cormelson rhizomes, were inedible, as werechipsfrom ' $M$ ian $\mathrm{Yu}^{\prime}$, due to the high acridity that remained after frying. Chips from the other cultivars had satisfactory appearance (value greater than 3 ), crispness, and taste, except for the taste of 'Bin Liang Xin' that was rated as poor ( T able 3). Chip oil content varied from about 19\% to 35\% 'N an An', 'Fujian special', 'Si M ao Yu', 'G aoxiong \#1', 'B in Liang $X i n$ ', and 'Bin Liang' the best overall chip taste, while ' $\mathrm{H}$ ong $\mathrm{G}$ eng $\mathrm{Yu}$ ' and 'M ian $\mathrm{Yu}$ ' had redder chip color than the other cultivars (T able 3 ).

Corm weight wasnegatively correlated with corm dry matter content while chip yield was positively correlated to corm weight matter content (Table 4). Taro chip oil content was negatively correlated to corm weight, dry matter, and chip yield. The oil percent in potato (Solanum tuber osum L.) chipsisnegatively correlated with tuber specific gravity, and positively correlated to chip yield ( L ulai and O rr, 1979; Gould, 1989), however, no similar relationships were found for taro cultivars (Table 4). O il uptake by potato chips is afunction of moisturereplacement, crust formation, interfacial tension, and capillary action (Saguy and Pinthus, 1995). Conflicting resultsmay berelated to the lower dry matter percentage and the lower specific gravity of taro cormsthan potato tubers. Taro chip yield was positively correlated to dry matter and chip oil percentage (T able4). Therewereno significant coefficients $(P>0.05)$ with corm specific gravity, corm total soluble solids, corm sugar, chip appearance, and chip crispness. The absence of these relationships may be relate to corm maturity, aslarger cormswereproduced on more mature plants.

$\mathrm{H}$ awaii Table and Poi Type C ultivars: Corm fresh weight and dry matter percentage varied widely from 372 to $1590 \mathrm{~g}$ (13.1 to $56.1 \mathrm{oz}$ ) and $12.4 \%$ to $44.4 \%$ respectively, while specific gravity varied within a narrow range between 0.8 to $1.01 \mathrm{mg} \cdot \mathrm{mL}^{-1}$ (T able 5). Corm total soluble solids ranged from $4.4 \%$ to $6.5 \%$ Corm flesh color varied from purple to orange and yellow and a similar range of variation occurred in poi made from these corms (T able 6 ).

The dry matter content of the poi varied from $18.3 \%$ to $48.3 \%$ and was linearly related $\left(r^{2}=0.811, P=0.0001\right)$ to corm dry matter percentage. The common taro cultivar used to make poi in $\mathrm{H}$ awaii is 'Lehua M aoli' (Table 6), however, the taste panel preferred poi

Table 4. Pearson correlation coefficients for relationships between taro chip quality parameter of fried and microwaved corm cultivars.

\begin{tabular}{|c|c|c|c|c|c|c|c|c|}
\hline \multirow[b]{2}{*}{ Parameter } & \multirow{2}{*}{$\begin{array}{c}\text { Corm } \\
\text { wt }\end{array}$} & \multirow{2}{*}{$\begin{array}{c}\text { Dry } \\
\text { matter }\end{array}$} & \multirow[b]{2}{*}{ Phenol } & \multirow{2}{*}{$\begin{array}{l}\text { Chip } \\
\text { yield }\end{array}$} & \multirow[b]{2}{*}{ Chip oil } & \multicolumn{3}{|c|}{ Color } \\
\hline & & & & & & $\mathbf{L}^{Y}$ & Chroma & H ue \\
\hline D ry matter & $-0.8252^{* * *}$ & & & & & & & \\
\hline Phenol & $-0.7373^{* *}$ & $0.7091^{* *}$ & & & & & & \\
\hline Chip yield & $0.8185^{* * *}$ & $0.9573^{* * * *}$ & $-0.7212^{* *}$ & & & & & \\
\hline Chip oil & $-0.6743^{*}$ & $-0.9129^{* * * *}$ & $0.6309^{*}$ & $-0.8452^{* * *}$ & & & & \\
\hline CIE L & NS & $0.5788^{*}$ & NS & $-0.6535^{*}$ & $-0.6544^{*}$ & & & \\
\hline Chroma & $0.6803^{*}$ & $0.8427^{* * *}$ & $0.6137^{*}$ & $-0.8837^{* * * *}$ & $0.8186^{* * *}$ & $0.8062^{* * *}$ & & \\
\hline $\mathrm{H}$ ue & $-0.7167^{* *}$ & $0.8339^{* * *}$ & $0.6632^{*}$ & $-0.8476^{* * *}$ & $0.8917^{* * * *}$ & $0.8783^{* * * *}$ & $0.9179^{* * *}$ & \\
\hline Taste & $0.6729^{*}$ & $-0.6777^{*}$ & NS & $-0.6935^{*}$ & NS & NS & NS & $-0.7434^{* *}$ \\
\hline
\end{tabular}

'“' $L^{\prime}$ C ommission I nternationale de I'E clairage ( $\mathrm{CIE}$ ), lightness value, dark to light.

$\mathrm{Ns}^{*}, * *, * * *, * * *$ Significant Pearson correlation coefficient nonsignificant or $\mathrm{P}<0.05,0.01,0.001$, or 0.0001 . 
Table 5. Corm characteristics of a range of boiled for table use and poi type taro cultivars grown at Moloka'i.

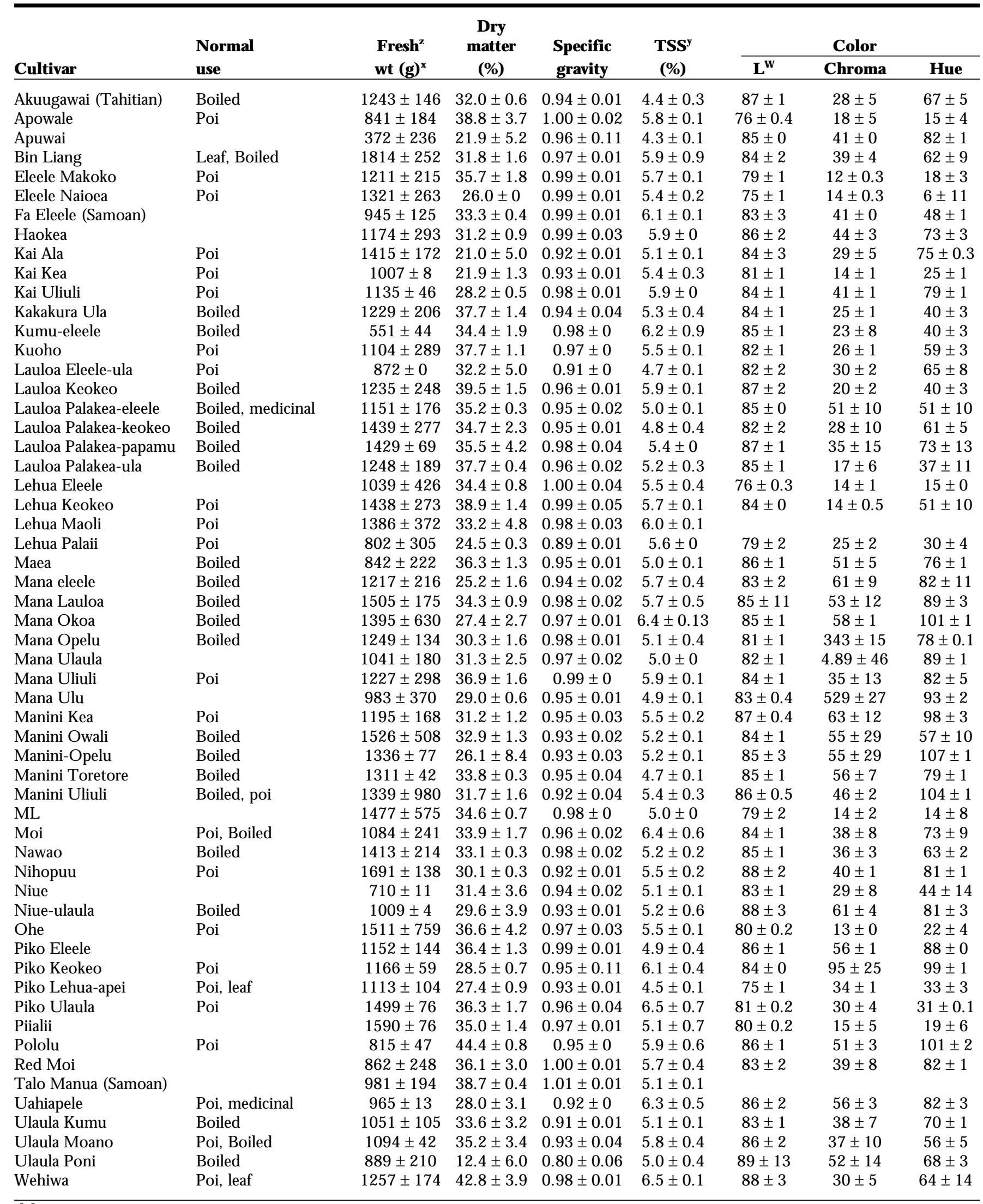

zM ean $\pm \mathrm{SD}$

yT SS $=$ total soluble solids.

${ }^{x} 1 \mathrm{~g}=0.035 \mathrm{oz}$.

w'L' Commission I nternationale de I'Eclairage (CIE), lightness value, dark to light. 
Table 6. Poi and microwaved corm characteristics of taro cultivars harvested at $\mathbf{1 0}$ months.

\begin{tabular}{|c|c|c|c|c|c|c|}
\hline \multirow[b]{2}{*}{ C ultivar } & \multirow{2}{*}{$\begin{array}{c}\text { Dry } \\
\text { matter }^{z} \\
(\%)\end{array}$} & \multicolumn{3}{|c|}{ Poi color } & \multicolumn{2}{|c|}{ Acceptability } \\
\hline & & $\mathbf{L}^{\mathbf{Y}}$ & Chroma & H ue & Poi & Microwaved \\
\hline Apowale & $44.3 \pm 2.0$ & $55 \pm 0.1$ & $10 \pm 2$ & $4 \pm 3$ & $4.46 \pm 0.78$ & $4.17 \pm 0.94$ \\
\hline Bin Liang & $38.6 \pm 1.0$ & $77 \pm 2.0$ & $40 \pm 8$ & $49 \pm 11$ & $2.69 \pm 1.74$ & $2.54 \pm 1.62$ \\
\hline E leele M akoko & $43.1 \pm 3.6$ & $57 \pm 3$ & $10 \pm 2$ & $8 \pm 5$ & $4.07 \pm 1.00$ & $4.15 \pm 1.14$ \\
\hline H aokea & $36.1 \pm 2.0$ & $72 \pm 0.5$ & $34 \pm 2$ & $73 \pm 0.2$ & & \\
\hline Kai Ala & $28.5 \pm 6.1$ & $66 \pm 1$ & $4 \pm 3$ & $27 \pm 13$ & $3.69 \pm 1.11$ & $3.58 \pm 1.24$ \\
\hline Kai Kea & $31.3 \pm 1.7$ & $62 \pm 2$ & $13 \pm 5$ & $28 \pm 8$ & $4.15 \pm 0.40$ & $3.73 \pm 1.22$ \\
\hline Kai U liuli & $34.3 \pm 3.8$ & $62 \pm 0.1$ & $3 \pm 0.6$ & $186 \pm 235$ & $3.60 \pm 1.18$ & $3.71 \pm 1.07$ \\
\hline Kakakura U la & $43.9 \pm 1.3$ & & & & $3.44 \pm 1.46$ & $3.40 \pm 1.24$ \\
\hline Kumu-eleele & $44.2 \pm 4.1$ & & & & $3.69 \pm 1.41$ & $3.73 \pm 1.35$ \\
\hline L auloa Palakea-keokeo & $38.1 \pm 2.8$ & $62 \pm 0.3$ & $4 \pm 0.1$ & $5 \pm 4$ & $4.08 \pm 0.94$ & $3.83 \pm 0.98$ \\
\hline L auloa Palakea-papamu & $39.0 \pm 0.9$ & $71 \pm 3$ & $27 \pm 2$ & $65 \pm 3$ & $3.60 \pm 1.06$ & $3.58 \pm 1.20$ \\
\hline L auloa Palakea-ula & $45.3 \pm 2.1$ & $62 \pm 1$ & $16 \pm 1$ & $27 \pm 1$ & $3.60 \pm 1.06$ & $3.57 \pm 1.22$ \\
\hline L ehua E leele & $38.9 \pm 0.7$ & $56 \pm 4$ & $10 \pm 1$ & $355 \pm 1$ & & \\
\hline L ehua Keokeo & $44.8 \pm 0.7$ & $67 \pm 1$ & $18 \pm 10$ & $47 \pm 5$ & $3.93 \pm 1.33$ & $4.27 \pm 1.10$ \\
\hline L ehua M aoli & $35.8 \pm 3.6$ & $58 \pm 3$ & $8 \pm 1$ & $1 \pm 0.1$ & $3.73 \pm 1.03$ & $4.00 \pm 1.00$ \\
\hline Lehua Palaii & $30.2 \pm 0.6$ & $66 \pm 1$ & $31 \pm 8$ & $43 \pm 5$ & $4.54 \pm 0.52$ & $4.17 \pm 1.19$ \\
\hline M aea & $44.9 \pm 4.0$ & $71 \pm 3$ & $75 \pm 8$ & $69 \pm 1$ & $4.46 \pm 0.78$ & $4.09 \pm 0.94$ \\
\hline M ana eleele & $33.7 \pm 4.4$ & $68 \pm 1$ & $13 \pm 0.4$ & $44 \pm 3$ & $3.93 \pm 1.08$ & $4.00 \pm 0.77$ \\
\hline$M$ ana Lauloa & $34.1 \pm 1.5$ & $67 \pm 1$ & $15 \pm 3$ & $54 \pm 13$ & $3.79 \pm 1.15$ & $3.77 \pm 0.97$ \\
\hline M ana O koa & $30.5 \pm 2.0$ & $71 \pm 1$ & $33 \pm 1$ & $55 \pm 1$ & $3.69 \pm 1.40$ & $3.62 \pm 1.56$ \\
\hline $\mathrm{M}$ ana $\mathrm{O}$ pelu & $33.6 \pm 1.6$ & $69 \pm 0.1$ & $633 \pm 17$ & $91 \pm 1$ & & \\
\hline M L & $41.3 \pm 2.5$ & $58 \pm 2$ & $9 \pm 1$ & $355 \pm 2$ & & \\
\hline M oi & $36.1 \pm 2.6$ & $66 \pm 1$ & $17 \pm 0.5$ & $47 \pm 7$ & & \\
\hline $\mathrm{N}$ awao & $38.9 \pm 3.6$ & $66 \pm 0.3$ & $29 \pm 1$ & $45 \pm 2$ & $3.93 \pm 0.88$ & $3.79 \pm 1.48$ \\
\hline $\mathrm{N}$ ihopuu & $31.2 \pm 1.1$ & $73 \pm 1$ & $25 \pm 10$ & $71 \pm 11$ & $3.91 \pm 1.41$ & $3.20 \pm 1.14$ \\
\hline $\mathrm{N}$ iue & $37.7 \pm 5.1$ & & & & $4.15 \pm 1.05$ & $3.50 \pm 1.16$ \\
\hline $\mathrm{N}$ iue-ulaula & $41.0 \pm 6.4$ & $69 \pm 2$ & $35 \pm 17$ & $67 \pm 5$ & $4.38 \pm 0.74$ & $4.00 \pm 0.95$ \\
\hline O he & $48.3 \pm 2.0$ & $57 \pm 4$ & $6 \pm 1$ & $4 \pm 5$ & & \\
\hline Piialii & $35.0 \pm 1.8$ & $56 \pm 3$ & $11 \pm 2$ & $177 \pm 245$ & & \\
\hline Piko Eleele & $37.6 \pm 0.4$ & $70 \pm 2$ & $24 \pm 4$ & $72 \pm 5$ & & \\
\hline Piko Keokeo & $29.8 \pm 0.4$ & $66 \pm 2$ & $5 \pm 3$ & $59 \pm 24$ & $3.87 \pm 0.92$ & $4.00 \pm 0.13$ \\
\hline Piko Lehua-apei & $22.4 \pm 0.9$ & $51 \pm 3$ & $12 \pm 5$ & $346 \pm 9$ & $3.38 \pm 1.5$ & $3.47 \pm 1.55$ \\
\hline Piko U laula & $35.8 \pm 2.6$ & $66 \pm 0.1$ & $14 \pm 2$ & $23 \pm 1$ & $3.67 \pm 1.45$ & $3.43 \pm 1.55$ \\
\hline Pololu & $48.5 \pm 1.9$ & $77 \pm 2$ & $47 \pm 19$ & $94 \pm 5$ & $4.00 \pm 0.82$ & $3.42 \pm 0.93$ \\
\hline Red M oi & $42.3 \pm 1.4$ & $69 \pm 0.5$ & $30 \pm 12$ & $73 \pm 2$ & $4.23 \pm 0.73$ & $4.08 \pm 0.67$ \\
\hline Talo M anua (Samoan) & $46.2 \pm 3.0$ & $65 \pm 0.1$ & $17 \pm 5$ & $50 \pm 3$ & $4.15 \pm 1.03$ & $3.92 \pm 1.24$ \\
\hline U ahiapele & $35.8 \pm 2.4$ & $72 \pm 1$ & $44 \pm 33$ & $76 \pm 11$ & $3.60 \pm 1.30$ & $3.50 \pm 0.80$ \\
\hline U laula Kumu & $43.1 \pm 2.3$ & $65 \pm 5$ & $11 \pm 3$ & $23 \pm 1$ & $3.29 \pm 1.2$ & $3.91 \pm 1.04$ \\
\hline U laula M oano & $38.8 \pm 2.4$ & $68 \pm 2$ & $20 \pm 9$ & $33 \pm 14$ & $4.00 \pm 1.13$ & $3.93 \pm 1.00$ \\
\hline U laula Poni & $18.3 \pm 5.9$ & $64 \pm 2$ & $41 \pm 37$ & $52 \pm 15$ & $3.47 \pm 1.46$ & $3.23 \pm 1.19$ \\
\hline Wehiwa & $45.4 \pm 2.4$ & $71 \pm 1$ & $35 \pm 1$ & $58 \pm 1$ & $3.33 \pm 1.45$ & $3.15 \pm 1.31$ \\
\hline
\end{tabular}

$\overline{\mathrm{z} M}$ ean $\pm \mathrm{SD}$.

$y^{`} L^{\prime}$ Commission Internationale de I'E clairage (CIE), lightness value, dark to light. 
Table 7. Pearson correlation coefficients and probability for relationships betwen poi and microwave corm taro taste panel preference and other corm or product characteristics.

\begin{tabular}{|c|c|c|c|c|}
\hline & \multicolumn{2}{|c|}{ Pearson correlation coefficient } & \multicolumn{2}{|c|}{$\mathbf{P}$} \\
\hline & Poi taste & Microwaved taste & Poi taste & M icrowaved taste \\
\hline Corm dry matter & -0.1213 & 0.0835 & ns & ns \\
\hline Specific gravity & 0.2519 & -0.0478 & 0.019 & ns \\
\hline Total soluble solids & -0.5626 & 0.3688 & $<0.0001$ & 0.0004 \\
\hline \multicolumn{5}{|l|}{ Corm CIE } \\
\hline $\mathrm{L}^{\mathrm{z}}$ & -0.0352 & -0.2781 & ns & 0.0095 \\
\hline Chroma & -0.0461 & -0.1608 & ns & ns \\
\hline $\mathrm{H}$ ue & -0.1253 & -0.1049 & ns & ns \\
\hline $\begin{array}{l}\text { Product dry matter } \\
\text { Product } \mathrm{CIE}\end{array}$ & 0.0079 & 0.1494 & ns & ns \\
\hline L & -0.8645 & 0.4614 & $<0.0001$ & $\varangle 0.0001$ \\
\hline Chroma & 0.9995 & -0.7111 & $\varangle 0.0001$ & $\varangle 0.0001$ \\
\hline H ue & 0.0408 & 0.0112 & ns & ns \\
\hline
\end{tabular}

'L' Commission I nternationale de I'E clairage (CIE), lightness value, dark to light.

${ }^{\mathrm{N}} \mathrm{N}$ onsignificant at $\mathrm{P}>0.05$

made from 'Eleele $\mathrm{N}$ aioea', 'Eleele Makoko', 'L auloaPalakea-keokeo', 'Kai kea', 'M anini Toretore', 'L ehua Palaii', 'A powale', 'Pololu', 'Red Moi', 'Talo $M$ anua', and 'N uie'. M icrowaved corm from 'L ehua M aoli' was the most preferred and highly regarded, and it along with 'L ehua Palaii', 'A powale', 'L ehua Keokeo', 'Eleele $\mathrm{N}$ aioea', 'Eleele Keokeo' had a higher acceptance than 'L ehuaM aoli' (T able6). 'E leeleN aioea', 'Lehua Palaii', and 'Apowale' had the highest taste acceptance both as microwaved corm and poi than by 'Eleele Makoko', 'N uie-ulaula', 'M aea', and 'Red M oi'.

Taste panel memberspreferred the poi and microwaved taro from thedarker bluish red corms (T able 7). There were negativecorrelation coefficientsbetween corm color "L" lightnessvalue, Chroma and hue and microwaved corm and poi taste, indicating that darker yellow boiled corm or poi were less liked. The dry matter percentage of corm was positively correlated with specific gravity (dry matter $=-61.0542+(97.7434 \times$ specific gravity); $\left.F \geq 0.0001, r^{2}=0.601\right)$. There were negative correlations between corm total soluble solids and both corm specific gravity ( $F \geq 0.0402$; $\left.r^{2}=0.273\right)$, and corm dry matter $(F \geq$ $\left.0.0563 ; r^{2}=0.254\right)$. M ealinessof cooked potatoes, (dry flaky texture), within a cultivar is high correlated to specific gravity but this relationship does not extend between cultivars (Liyan and Smith, 1964). H owever, no significant correlations were found between the taste of different poi or boiled types and corm specific gravity (Table 7). Potato specific gravity is influenced by genetics and environmental growing conditions (Gould, 1989). Poi and microwaved corm taste was possibly more dependent upon texture and viscosity however, these mouth feel textural characteristic are not easily determined and are related to cell strength in potatoes (N onaka and Timm, 1983).

Considerablevariation occurred in the yield and quality of fried chip, microwaved corm and poi made from taro corms. Thisfinding agrees with the reported phenotypic variations(Whitney et al. 1939), isozymic variation (Lebot and Aradhya, 1991) and ploidy level (Zhang and Zhang, 1990) of cultivated taro. Cultivated taro is propagated vegetatively and sexual reproduction is rare in cultivated materials, though it may occur in the wild (M atthews, 1997). The variation in taro and corm characteristics and differences in human preferencesfor fried chips, microwaved corm and poi made from different cultivars makethiswidelydistributed crop, adaptable to many situations.

\section{Literature cited}

Amin, E.S. 1955. The polysaccharides of Colocasia antiquorum (Taro or Colocasia). J. Chem. Soc. Part III. p. 2441-2445.

Bradbury, J.H. 1988. The chemical composition of tropical root crops. Assn. S.E. Asian N ations (ASEAN) Food J. 4:3-13.

Dubois, D., K.A. Gilles, J.K. H amilton, P.A. Rebers, and F. Smith. 1956. Colorimetric method for determination of sugars and related substances. Anal. Chem. 28:350-356.

Gould, W.A. 1989. Q uality of potatoes for chip manufacture. Amer. Potato J. 66:(5)Supplement p. 10-20.

Liyan, L. and O. Smith. 1964. Potato quality XXIV. O bjective measurement of mealinessin potatoes. Amer.
Potato J. 41:244-252.

Lebot, V. and K.M. Aradhya. 1991. I sozyme variation in taro (C olocasia esculenta (L.) Schott) from Asia and O ceania. E uphytica 56:55-66.

Lulai, E.C. and P.H. O rr. 1979. Influence of potato specific gravity on yield and oil content of chips. Amer. Potato J. 56:379-390.

M atthews, P.J. 1997. Field guide for wild-type taro, Colocasia esculenta (L.) Schott. Plant G enetic Resources N wslt. 110:41-48

M cGuire, R. 1992. Reporting of objective color measurement. H ortScience 27:1254-1255

N onaka, M. and H. Timm. 1983. Textural quality of cooked potatoes: II. Relationship of stram cooking time to cellular strength of cultivars with similar and differing solids. Amer. Potato J. 60:685-692.

Paull, R.E., C.S. Tang, K. Gross, and G. U ruu. 1999. The nature of the taro acidity factor. Postharvest Biol. Technol. 16:71-78.

Payne, J.H., G.J . Ley, and G. Akau. 1941. Processing and chemical investigations of $\mathrm{T}$ aro. $\mathrm{U}$ niv. $\mathrm{H}$ awaii Agr. Expt. Sta. Bul. 86.

Plucknett, D.L., R.S. D ela Pena, and F. O brero. 1970 Taro (Colocasia esculenta). Field Crop Abstr. 23:413426.

Plucknett, D.L. 1970. Colocasia, X anthosoma, A locasia, Cyrtosperma and A morphophallus, p. 127-135. In. D.L. Plucknett (ed.). Proc 2 nd Intl. Symp. Tropical R oot and Tuber Crops. College of Tropical Agr., U niv. $\mathrm{H}$ awaii, H onolulu.

Saguy, I.S. and E.J. Pinthus. 1995. Oil uptake during deep fat frying: Factors and mechanism. Food Technol. 49(4):142-145, 152.

Singleton, V.L. and J.A. Rossi. 1965. Colorimetry of total phenolics with phosphomolybolic-phosphotungstic acid reagent. Amer. J. Enol. Viticult. 16:144-158.

Standal, B.R. 1970. The nature of poi carbohydrates, $p$ 146-148. In. D.L. Plucknett (ed.). Proc. 2nd II. Symp. Tropical Root and Tuber Crops. College of Tropical Agr., U niv. $\mathrm{H}$ awaii, $\mathrm{H}$ onolulu.

Whitney, L.D ., F.A.I . Bowers, and M . Takahashi. 1939. Taro varieties in $\mathrm{H}$ awaii. $\mathrm{U}$ niv. $\mathrm{H}$ awaii Agr. Expt. Sta. Bul. 84.

Zhang, G.M. and D.X. Zhang. 1990. The relationship between geographic distribution and ploidy level of taro, Colocasia esculenta. Euphytica 47:25-27. 